\title{
Cheiromyces lignicola, a new chirosporous anamorphic species from Hong Kong
}

\author{
Wai-Hong $\mathrm{Ho}^{1}$ \\ I. John Hodgkiss \\ Kevin D. Hyde \\ Centre for Research in Fungal Diversity, Department of \\ Ecology and Biodiversity, The University of Hong \\ Kong, Pokfulam Road, Hong Kong
}

\begin{abstract}
Cheiromyces lignicola sp. nov. is described and illustrated from a freshwater stream in Hong Kong. The species is characterized by chiroid, yellowish brown, distoseptate conidia that are composed of 3-5 arms, each terminating apically in an inflated cell. The developmental stages of the inflated apical cell are illustrated. Cheiromyces lignicola is compared with other Cheiromyces species, and other taxa that produce chiroid conidia with inflated apical cells. The taxonomic disposition of C. cubensis and $C$. wrightii in Cheiromyces is also discussed. Keys to species of Cheiromyces and to 26 anamorphic genera that produce chiroid conidia are provided.

Key Words: aquatic fungi, chiroconidia, freshwater fungi, hyphomycetes, lignicolous fungi, systematics, taxonomy
\end{abstract}

\section{INTRODUCTION}

In a continuing study of freshwater mycota in the tropics (Ho et al 1997, 1999a, b, c, Goh et al 1998b, Hyde et al 1999), an undescribed dematiaceous hyphomycete was found on wood baits of Machilus velutina Champ. and Pinus massoniana Lamb. and wood naturally submerged in a small stream in Hong Kong. This fungus produced chiroid conidia in sporodochia. Morphological characters indicate that it is an undescribed species of Cheiromyces Berk. \& M. A. Curtis.

Cheiromyces was described by Berkeley (1875) with C. stellatus Berk. \& M. A. Curtis as the only species. Two specimens were cited in the protologue, viz. No. 4883, on culms of Scirpus eriophorus, and No. 5087, on "a Sphaeropsis." Berkeley described C. stellatus as having nonseptate conidia. However, based on an examination of specimen No. 5087, Martin (1944) and

Accepted for publication December 23, 1999.

${ }^{1}$ Email: wellcomeho@hotmail.com
Damon (1950) established that the genus has septate conidia, and characterized it as such. Subsequently, Sutton (1985) designated specimen No. 4883 as lectotype, and restricted the genus to species having distoseptate conidia. Nine species producing euseptate conidia were excluded by Sutton (1985), leaving the genus monospecific.

Three additional species have been described: $C$. cubensis Matsush., from decaying leaf rachis of royal palm, Roystonea regia (Kunth) Cook, in Cuba, C. recurvus V. G. Rao \& De Hoog from rotten wood in India and C. wrightii Aramb. et al on wood and bark from the Santiago River in Argentina. The conidia of C. cubensis and C. wrightii are apparently euseptate (Arambarri et al 1987, Matsushima 1987) and possibly these species should not be included in Cheiromyces. No Cheiromyces species has been linked to a teleomorph.

The lectotype specimen of $C$. stellatus is characterized by the presence of punctiform, sporodochial conidiomata that lack obvious conidiophores, discrete, monoblastic conidiogenous cells that do not proliferate; holoblastic, pale brown conidia that are composed of a truncate basal cell upon which 3-5 straight, vertical, appressed or slightly divergent, cylindrical, distoseptate arms are formed in different planes; and schizolytic secession (Sutton 1985). The conidia of $C$. recurvus possess 5-6 arms that are 1014-distoseptate, with a marked ring of pigmentation around the septal pores (Rao and De Hoog 1986). In C. cubensis, conidia have 1-5 (mostly 4) arms that are 5-15-septate and constricted at the septa (Matsushima 1987), while in $C$. wrightii, conidia possess 3-5 arms that are 3-5-septate and constricted at the septa (Arambarri et al 1987).

\section{TAXONOMY}

Cheiromyces lignicola W. H. Ho, K. D. Hyde et I. J. Hodgkiss, sp. nov. FIGS. 1-12

Conidiomata sporodochia, sparsa, punctiformia, pulvinata, atrobrunnea vel atra, 150-350 $\mu \mathrm{m}$ diam. Mycelium in substrato immersum, ex hyphis pallide brunneis, laevibus, tenuitunicatis, septatis, ramosis compositum. Conidiophora absens. Cellulae conidiogene monoblasticae, integratae, terminales, determinatae, hyalinae vel pallide brunneae, oblongae, 5-7.5 $\times 3.5-5 \mu \mathrm{m}$, laeve, tenuitunicatae, maturere insimul, non proliferatinibus. Conidia acrogenosa, holo- 

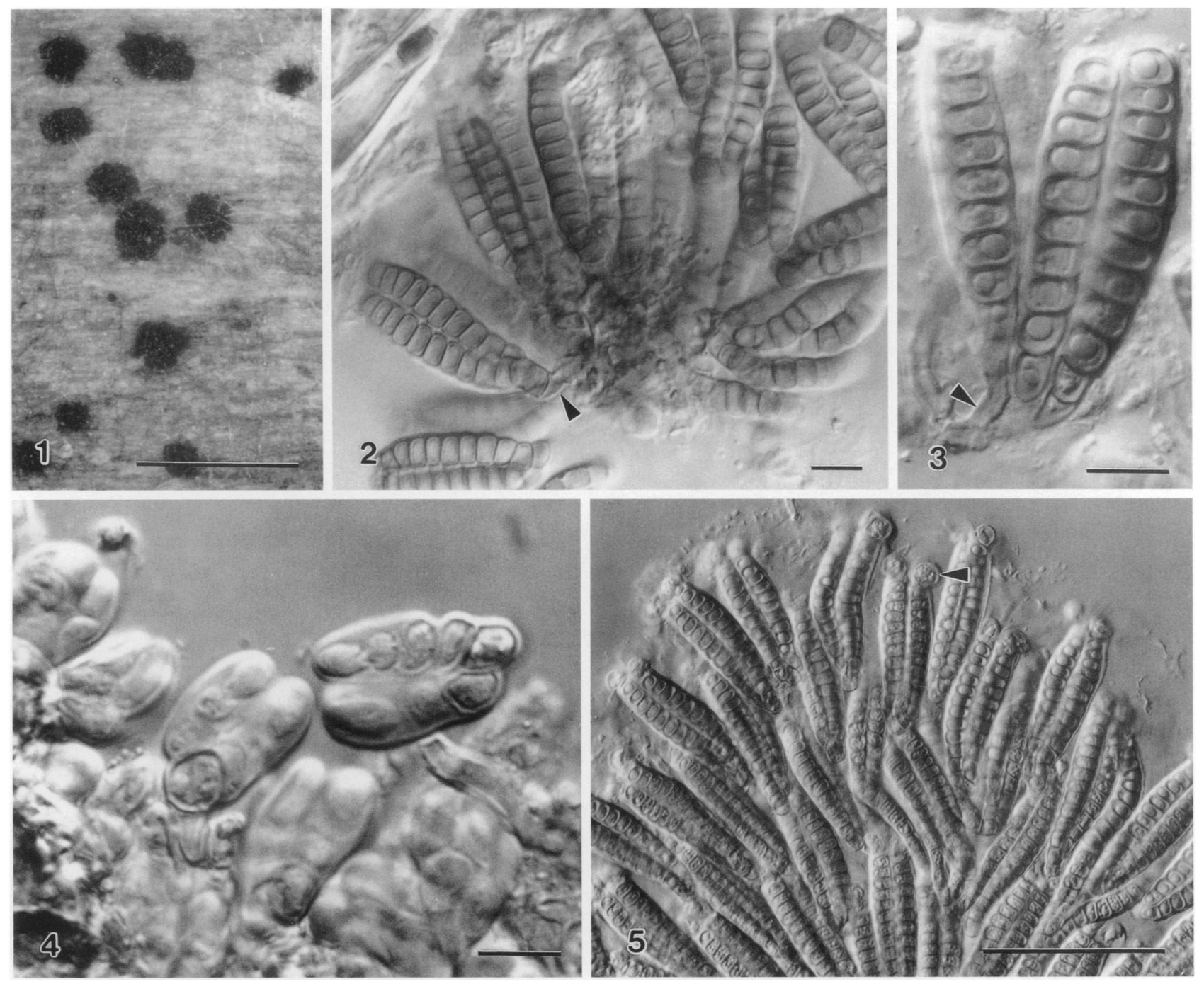

FIGs. 1-5. Cheiromyces lignicola (from HOLOTYPE). 1. Sporodochia on wood substratum. 2, 3. Conidia in sporodochia, illustrating the conidiogenous cells (arrowheads). 4. Immature hyaline conidia. 5. Mass of mature conidia. Note the inflated apical cells (arrowhead). 1. Stereo micrograph. 2-5. Interference light micrographs. 2. In lacto-phenol. 3-5. In water. Bars: $1=1 \mathrm{~mm} ; 2-4=10 \mu \mathrm{m} ; 5=50 \mu \mathrm{m}$.

blastica, solitaria, hyaline cum immatura, pallide fulva ad maturita, chiroidea, 30-60 × 10-14 $\mu \mathrm{m}$, distoseptata, cum $3-4(-5)$ rami praedita, verticalia; cellula basilaris pallide brunnea, truncata, 3-5.5 $\times 3.5-4.5 \mu \mathrm{m}$, laevia, tenuitunicata; rami discreti, non ramosi, dense appressi vel modice divergenti, cylindrici, 28-55 × 6-8 $\mu \mathrm{m}, 5-12$-distoseptati, ad septa haud constricti, omne brachi cum celluli apicalis turgidi; cellula apicalis turgidus hyalina, globosa vel subglobosa, 5-7.5 $\mathrm{mm}$ diam, laevia, crassitunicata, tum tenuitunicata, postremo fastiscens. Conidiorum secessio rhexolytica.

Conidiomata sporodochial, scattered, punctiform, pulvinate, dark brown to black, 150-350 $\mu \mathrm{m}$ diam (FIG. 1). Mycelium immersed in the substratum, composed of pale brown, smooth, thin-walled, septate, branched hyphae. Conidiophores absent. Conidiogenous cells monoblastic, integrated, terminal, determinate, hyaline or pale brown, oblong, 5-7.5 $\times$
3.5-5 $\mu \mathrm{m}$, smooth, thin-walled, giving rise to a single crop of conidia that mature synchronously, not proliferating (FIGs. 2, 3). Conidia acrogenous, holoblastic, solitary, hyaline when immature, pale yellowish brown at maturity, chiroid, 30-60 × 10-14 $\mu \mathrm{m}(\bar{x}=$ $47 \times 11.8 \mu \mathrm{m}, \mathrm{n}=30)$, distoseptate, with $3-4(-5)$ arms vertically inserted, in different planes, on basal cells (FIGS. 4-12); basal cells pale brown, truncate, 3$5.5 \times 3.5-4.5 \mu \mathrm{m}$, smooth, thin-walled (FIGS. 4, 7, 11, 12); arms discrete, unbranched, closely appressed to each other or slightly divergent, cylindrical, 28-55 $\times$ 6-8 $\mu \mathrm{m}, 5-12$-distoseptate, not constricted at the septa, each arm with an inflated apical cell (FIGS. 5-12); inflated apical cells hyaline, globose to subglobose, 5-7.5 $\mu \mathrm{m}$ diam, smooth, with wall that is initially thick (FIGS. 6-9), but thin at later stages (FIG. 10), 

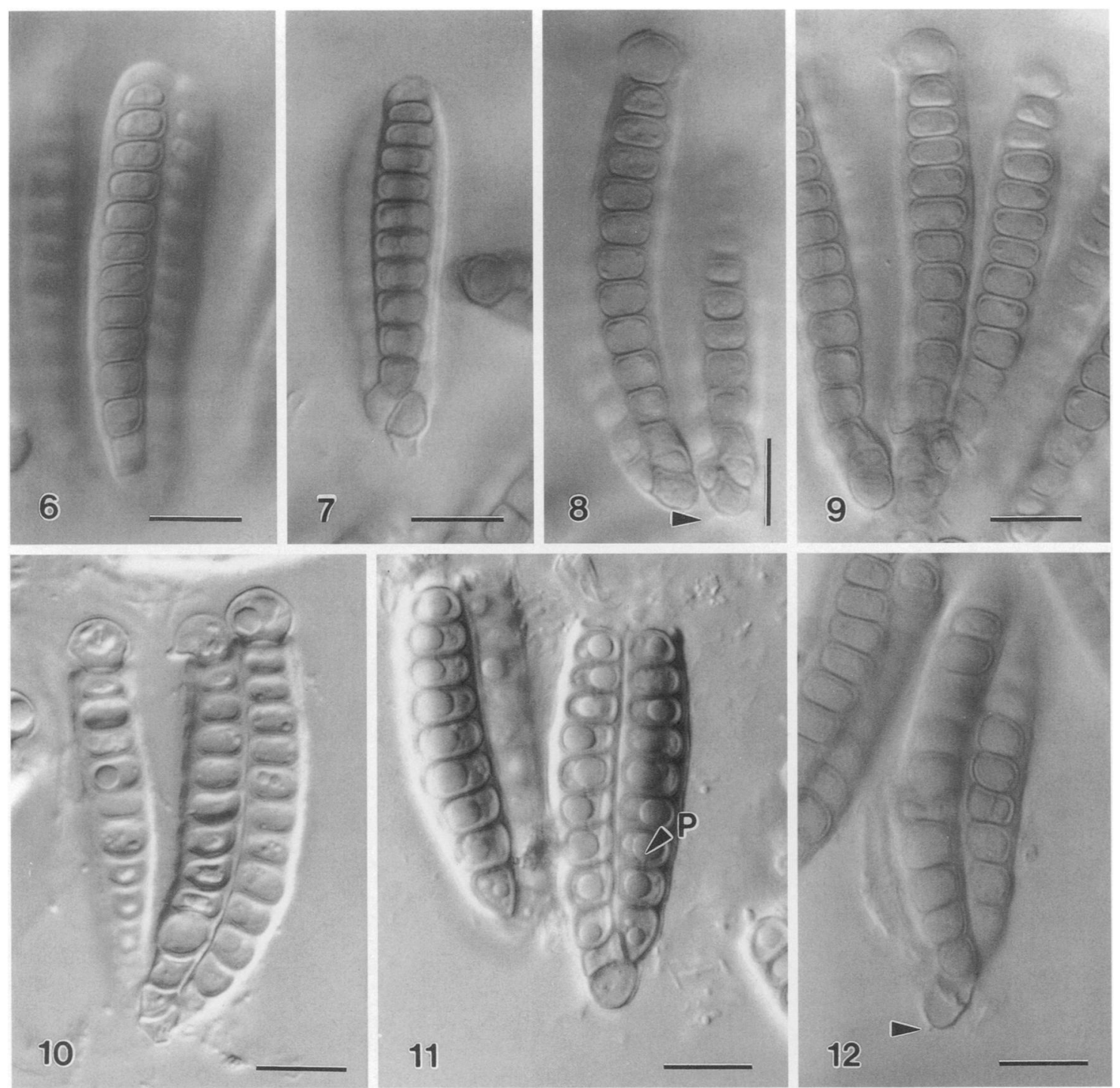

FIsis. 6-12. Cheiromyces lignicola (from HOLOTYPE). 6-10. Conidia with developmental sequence of apical cells. 11. Conidia with disintegrated apical cells. Note the septal pores $(\mathrm{P})$. 12. Conidia with a frill of remnants of conidiogenous cells after secession. 6-12. Interference light micrographs. 6-9, 12. In lacto-phenol. 10, 11. In water. Bars $=10 \mu \mathrm{m}$.

and may eventually disintegrate (FIG. 11). Conidial secession rhexolytic (FIG. 12).

Materials examined. HONG KONG. Tai Po Kau Forest Stream, on submerged decaying wood, 29 Dec 1996, W. H. Ho \& S. Y. Ho WH316 [HOLOTYPE HKU(M) 5937]; on submerged wood, 29 Mar 1997, W. H. Ho [HKU(M) 5982]; on Machilus velutina wood bait, 29 Mar 1997, W. H. Ho [HKU(M) 6039]; on Pinus massoniana wood bait, 28 Jun 1997, W. H. Ho [HKU(M) 6146].

Etymology. In reference to the woody substratum.

Known distribution. Hong Kong.

Habitat. Saprobic on decaying wood in streams.

Teleomorph. Unknown.

Commentary. Cheiromyces lignicola differs from the type species, C. stellatus, and from $C$. recurvus, both of which also produce distoseptate conidia. Conidia in C. lignicola are pale yellowish brown with 3-5 apically inflated conidial arms. Conidia in C. stellatus are brown with 3-5 conidial arms that have longer apical cells (Sutton 1985), while conidia in C. recurvus are pale brown with 5-6 apically recurved conidial arms (Rao and De Hoog 1986). In C. recurvus, marked rings of pigmentation, visible in lateral view as a dark brown disc, are present in all conidium delimiting and conidial septa (Rao and De Hoog 1986). Similar rings are not found in C. stellatus (Sutton 1985) or in C. lignicola. A pigmented ring surrounding septal pores has been recorded in euseptate conidia in other fungi, such as Digitodesmium recurvum W. H. Ho et al (Ho et al 1999a); in distoseptate conidia, as found in Pyricularia peruamazonica Matsush. (Mat- 
sushima 1993); or in conidia with both distosepta and eusepta, as found in Janetia curviapicis Goh \& K. D. Hyde (Goh and Hyde 1996). A pigmented septal ring is recognized as a generic character in Canalisporium Marvanová (Goh et al 1998a). Bactrodesmium Cooke (Ellis 1971) includes species with and without the pigmented ring.

Cheiromyces lignicola is distinguished by its conidial arms with inflated apical cells. Developmental stages of the apical cells are illustrated in Figs. 610. It is evident that the apical cells are initially thick-walled; this development is followed by an increase in size, and subsequently the outer wall disintegrates leaving the thin inner wall. The apical cells disintegrate at maturity (FIG. 2, 3, 11). Conidia failed to germinate on water agar and potato dextrose agar at $24 \mathrm{C}$.

Several fungi with euseptate conidia produce conidia with inflated apical cells. Cheiromyces inflatus Matsush. produces such conidia (Matsushima 1983). Sutton (1985) considered this fungus better placed in Cheiromycella Höhn. because of its euseptate conidia. Cheiromyces lignicola can be compared to Cheiromycella moniliphora Matsush. (Matsushima 1981), Dictyosporium alatum Van Emden (1975), D. bulbos$u m$ Tzean \& Chen (Tzean and Chen 1989) and $D$. digitatum Chen et al (1991), all of which produce chiroid conidia with inflated apical cells. All of these latter species produce euseptate conidia, however, clearly distinguishing them from C. lignicola.

Placement of $C$. cubensis and C. wrightii in Cheiromyces appears to be inappropriate. As mentioned earlier, the initial concept of Cheiromyces was confused because the syntypes had, respectively, euseptate and distoseptate conidia. Sutton (1985) restricted the genus to species that produce distoseptate conidia. The line drawings that accompany the descriptions of $C$. cubensis and $C$. wrightii suggest that these species are euseptate (Matsushima 1987, Arambarri et al 1987); if this is the case, they must be redisposed. Examination of the original material is necessary before such disposition can be made.

Conidial secession in C. lignicola is rhexolytic. Following secession, some conidia retain a basal frill that consists of wall remnants of the conidiogenous cell. Conidial secession in C. stellatus was described as schizolytic (Sutton 1985), while the illustrations of $C$. recurvus indicated no remnants of conidiogenous cell at the base of the detached conidia (Rao and DeHoog 1986). It is possible that conidia with a basal frill were overlooked, as was the case in Canalisporium. In Canalisporium, conidia were described as seceding schizolytically (Nawawi and Kuthubutheen 1989), but secession in the latter was shown to be rhexolytic (Goh et al 1998a).

\section{KEY TO SPECIES OF CHEIROMYCES}

A key to species of Cheiromyces, including the doubtful species C. cubensis and C. wrightii, is based on literature.

1. Conidia with inflated apical cells $\ldots \ldots \ldots \ldots \ldots 2$

1. Conidia without inflated apical cells . . . . . . 3

2. Conidia with 3-5 conidial arms; conidial arms 28$55 \times 6-8 \mu \mathrm{m}$, unbranched, 5-12 septate, without constriction at the septa .......... . lignicola

2. Conidia with 1-5 conidial arms; conidial arms 20$60 \times 3-5 \mu \mathrm{m}$, branched near the basal cells, 5-15 septate, with slight constriction at the septa ... $\ldots \ldots \ldots \ldots \ldots \ldots$. cubensis

3. Conidia with recurved apical cells $\ldots \ldots$. C. recurvus

3. Conidia without recurved apical cells . . . . . . . 4

4. Conidial arms 23-30 $\times 4-6 \mu \mathrm{m}$, without constriction at the septa ........... stellatus

4. Conidial arms 13-22 $\times 4-5 \mu \mathrm{m}$, with slight constriction at the septa .......... C. wrightii

\section{KEY TO CHIROSPOROUS GENERA}

In addition to Cheiromyces, 26 genera of anamorphic fungi produce chiroid conidia. Of these, 2 produce distoseptate conidia and 24 produce euseptate conidia. A key to these genera, based on literature, is provided.

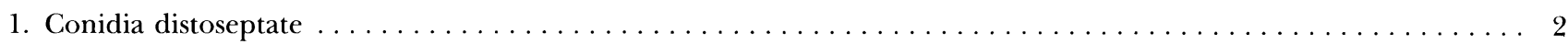

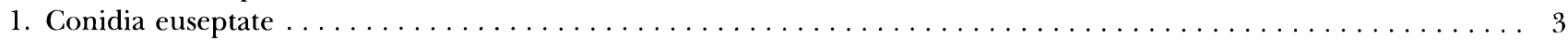

2. Conidial arms arising from single basal cells, conidia formed at one level, nonlichenized . . . . . . . Cheiromyces

2. Conidial arms formed from a series of dichotomous branches, conidia formed at many levels, lichenized .....

$\ldots \ldots \ldots \ldots \ldots \ldots \ldots$ Cheiromycina B. Sutton (Sutton and Muhr 1986, Hawksworth and Poelt 1990)

3. Conidia recurved, forming arms pointing downwards $\ldots \ldots \ldots \ldots \ldots \ldots$

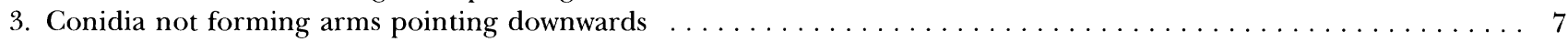

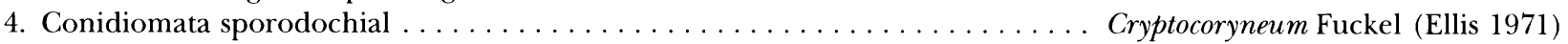

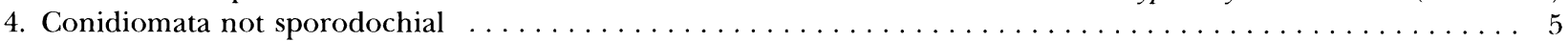

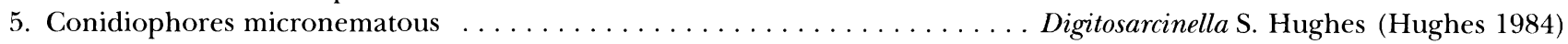

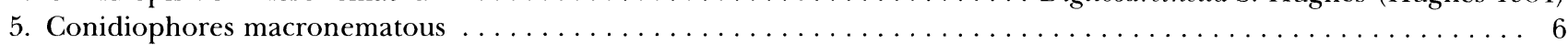

6. Conidiogenous cells enteroblastic, proliferating percurrently . . . Eversia J. L. Crane \& Schokn. (Schoknecht and Crane, 1977, Holubová-Jechová 1987)

6. Conidiogenous cells holoblastic, not proliferating .......... Cryptocoryneopsis B. Sutton (Sutton 1980a) 


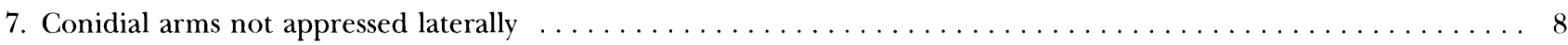

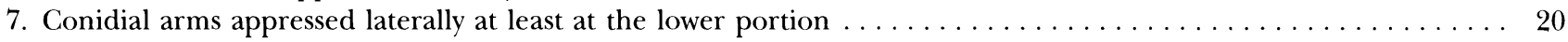

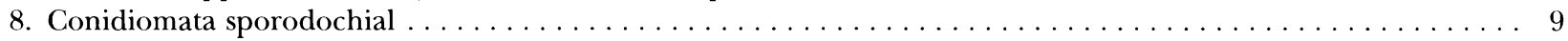

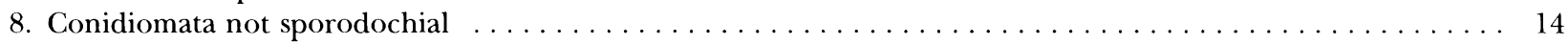

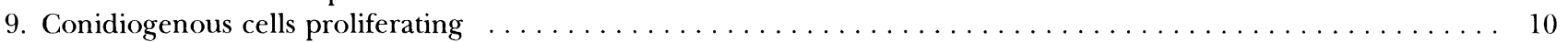

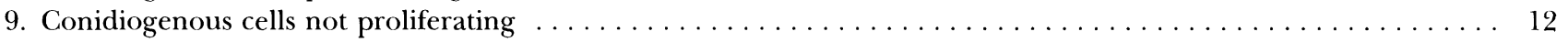

10. Conidiogenous cells enteroblastic, proliferating percurrently . . Ramoconidiifera B. Sutton et al (Sutton et al. 1996)

10. Conidiogenous cells holoblastic, proliferating sympodially $\ldots \ldots \ldots \ldots \ldots \ldots \ldots \ldots \ldots$

11. Conidiophores constricted strongly at the septa, composed mainly of swollen conidiogenous cells that are sometimes

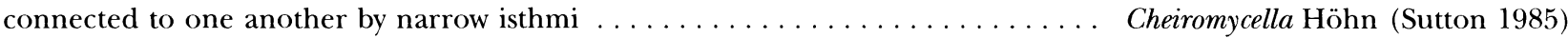

11. Conidiophores cylindrical, cells not constricted at the septa . . Dicranidion Harkn. (Peek and Solheim 1958, Ando and Tubaki 1984)

12. Conidial arms seceding at the basal cell .. Petrakiopsis Subram. \& K. R. C. Reddy (Subramanian and Reddy 1968)

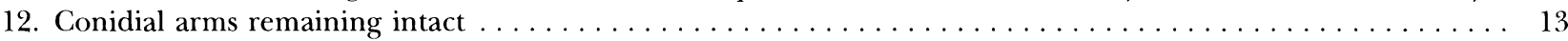

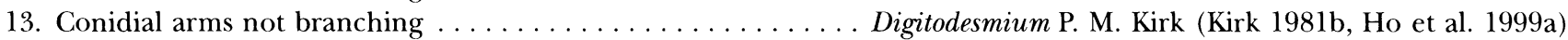

13. Conidial arms branch, with all arms parallel with and connected to each other at intermediate length of the conidia

$\ldots \ldots \ldots \ldots \ldots \ldots \ldots \ldots \ldots \ldots \ldots \ldots \ldots \ldots \ldots \ldots \ldots \ldots \ldots \ldots \ldots$ Amallospora Penz. (Penzig 1897, Carmichael et al 1980)

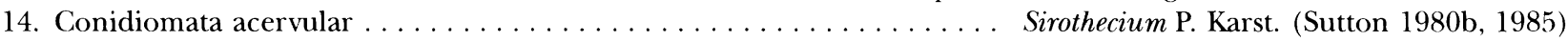

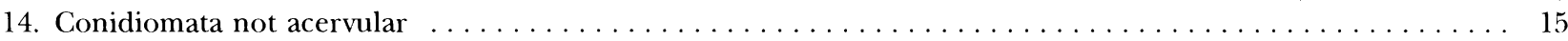

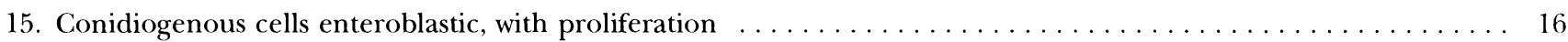

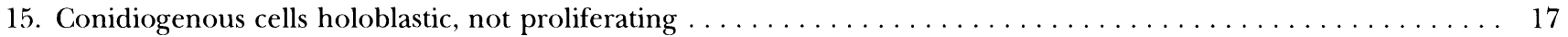

16. Conidiogenous cells proliferating percurrently .. Ceratosporella Höhn. (Kuthubutheen and Nawawi 1991, Castañeda-Ruiz et al. 1996)

16. Conidiogenous cells proliferating sympodially ............. Dendryphion Wallr. (Carmichael et al 1980)

17. Conidial arms branch from the basal cells in whorl-shape ... Nidulispora Nawawi \& Kuthub. (Nawawi and Kuthubutheen 1990)

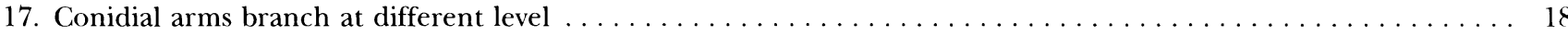

18. Conidia branch dichotomously ........... Cladoconidium Bandoni \& Tubaki (Bandoni and Tubaki 1985)

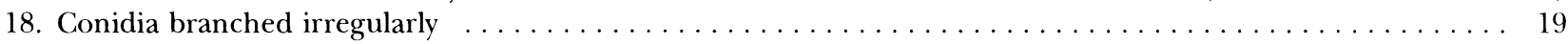

19. Conidiophores micronematous ... . . . Taeniolina M. B. Ellis (Ellis 1976, Kirk 1981a, Crane and Schoknecht 1981)

19. Conidiophores macronematous ... . . . . . . Goosiomyces N. K. Rao \& Manohar. (Rao and Manoharachary 1989)

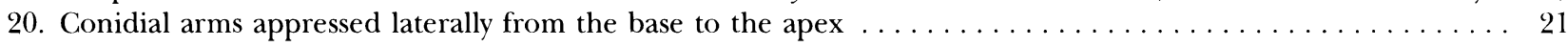

20. Conidial arms appressed laterally at the lower portion, with separating arms at the apex $\ldots \ldots \ldots 24$

21. Conidiomata sporodochial, conidiogenous cells not proliferating . . . . . . Dictyosporium Corda (Goh et al. 1999)

21. Conidiomata not sporodochial, conidiogenous cells proliferating $\ldots \ldots \ldots \ldots 2$ 22. Conidiogenous cells holoblastic, proliferating sympodially ... Cheiromoniliophora Tzean \& J. L. Chen (Tzean and Chen 1990, Castañeda-Ruiz et al. 1997a, b)

22. Conidiogenous cells enteroblastic, proliferating percurrently $\ldots \ldots \ldots \ldots \ldots \ldots \ldots$

23. Conidiophores macronematous, with oval basal cells on tubular conidiophores ... Pseudodictyosporium Matsush. (Matsushima 1971)

23. Conidiophores semi-macronematous, conidiogenous cells composed of spherical, verruculose, catenulate cells Cheiropolyschema Matsush. (Matsushima 1980, Bhat and Kendrick 1993)

24. Conidiogenous cells holoblastic, not proliferating .. Tetraploa Berk. \& Broome (Ellis 1971, Arambarri et al. 1987, Rifai et al. 1988)

24. Conidiogenous cells enteroblastic, with or without proliferation $\ldots \ldots \ldots \ldots$

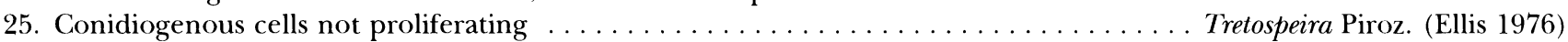

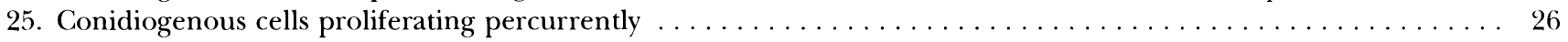

26. Conidial arms in different planes ....... Hughesinia J. C. Lindq. \& Gamundí (Lindquist and Gamundí 1970) 26. Conidial arms in one plane ... Piricaudiopsis J. Mena \& Mercado (Mena-Portales and Mercado-Sierra 1987, Bhat and Kendrick 1993)

\section{ACKNOWLEDGMENTS}

The authors thank the staff in the Photographic Unit of the Faculty of Science, The University of Hong Kong for photographic assistance. Ms. Helen Y. M. Leung is thanked for technical assistance. W. H. Ho would like to thank The University of Hong Kong for the award of a postgraduate studentship.

\author{
(1)
}

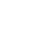

(1)

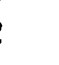

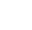


Bandoni RJ, Tubaki K. 1985. Cladoconidium: a new hyphomycete anamorph-genus. Trans Mycol Soc Japan 26: 425-431.

Berkeley MJ. 1875. Notices of north American fungi. Grevillea 3:97-112.

Bhat DJ, Kendrick WB. 1993. Twenty-five new conidial fungi from the western Ghats and the Andaman Islands (India). Mycotaxon 49:19-90.

Carmichael JW, Kendrick WB, Conners IL, Sigler L. 1980. Genera of Hyphomycetes. Edmonton, Alberta, Canada: The University of Alberta Press. 386 p.

Castañeda-Ruiz RF, Gurarro J, Cano J. 1996. Notes on conidial fungi: X. A new species of Ceratosporella and some new combinations. Mycotaxon 60:275-281.

_ -1997 a. Notes on conidial fungi: XI. Two new species of Cheiromoniliophora and Oncopodium. Mycotaxon 61:319-326.

- - — Figueras MJ, Gene J, Cano J. 1997b. More conidial fungi from La Gomera, Canary Islands, Spain. Mycotaxon 65:121-131.

Chen JL, Hwang CH, Tzean SS. 1991. Dictyosporium digitatum, a new hyphomycete from Taiwan. Mycol Res 95: 1145-1149.

Crane JL, Schoknecht JD. 1981. Revision of Torula spp.: Pseudoaegerita corticalis, new genus new combination, Taeniolina deightonii, new species and Xylohypha bowdichiae, new combination. Mycologia 73:78-87.

Damon SC. 1950. A taxonomic consideration of two cheirosporous genera, Cheiromyces and Pedilospora. Mycologia 42:554-562.

Ellis MB. 1971. Dematiaceous hyphomycetes. Kew, Surrey, UK: Commonwealth Mycological Institute. 608 p.

- 1976. More dematiaceous hyphomycetes. Kew, Surrey, UK: Commonwealth Mycological Institute. 507 p.

Goh TK, Ho WH, Hyde KD, Whitton SR, Umali TE. 1998a. New records and species of Canalisporium (Hyphomycetes), with a revision of the genus. Can J Bot 76:142152.

- Hyde KD. 1996. Janetia curviapicis, a new species, and an emended description of the genus. Mycologia 88:1014-1021.

,-- Ho WH. 1998b. Aquaphila albicans gen. et sp. nov. (Hyphomycetes) from submerged wood in the tropics. Mycol Res 102:587-592.

,,--- Y Yanna. 1999. A revision of the genus Dictyosporium, with descriptions of three new species. Fung Divers 2:65-100.

Hawksworth DL, Poelt J. 1990. A second lichen-forming species of Cheiromycina from Austria. Lichenologist 22: 219-224.

Ho WH, Hyde KD, Hodgkiss IJ. 1997. Ascomycetes from tropical freshwater habitats: the genus Savoryella, with two new species. Mycol Res 101:803-809.

$\longrightarrow,-1999$ a. Digitodesmium recurvum, a new species of chirosporous hyphomycetes from Hong Kong. Mycologia 91:900-904.

,$--1999 \mathrm{~b}$. Ultrastructural study of $A n$ nulatascus aquaticolus sp. nov., a freshwater ascomycete. Fung Divers 2:119-128.

—, Ranghoo VM, Hyde KD, Hodgkiss IJ. 1999c. Ascal ultrastructural study in Annulatascus hongkongensis sp. nov., a freshwater ascomycete. Mycologia 91:885-892.

Holubová-Jechová V. 1987. Studies on Hyphomycetes from Cuba: V. Six new species of dematiaceous Hyphomycetes from Havana Province. Ceská Mykol 41:29-36.

Hughes SJ. 1984. Digitosarcinella caseariae n. gen., n. sp. and Questieriella synanamorphs of the so-called Amazonia caseariae. Can J Bot 62:2208-2212.

Hyde KD, Ho WH, Tsui KM. 1999. The genera Aniptodera, Halosarpheia, Nais and Phaeonectriella from freshwater. Mycoscience 40:165-183.

Kirk PM. 1981a. New or interesting microfungi: dematiaceous hyphomycetes from Devon, England, UK. Trans Br Mycol Soc 76:71-88.

- 1981b. New or interesting microfungi. Trans Br Mycol Soc 77:279-297.

Kuthubutheen AJ, Nawawi A. 1991. A new species of Ceratosporella and Triposporium lambdaseptatum, new combination (Matsush.) from Malaysia. Mycol Res 95:158-162.

Lindquist JC, Gamundí IJ. 1970. Hughesinia, nuevo genero de Hifomicetes (Demaciacea). Boln Soc Argent Bot 13: 53-57.

Martin GW. 1944. The fungus genus Cheiromyces, with description of a new species. J Wash Acad Sci 34:358-360.

Matsushima T. 1971. Microfungi of the Solomon Islands and Papua New Guinea. Kobe, Japan: Publ by author. $78 \mathrm{p}$.

- 1980. Saprophytic microfungi from Taiwan. Part I. Hyphomycetes. Kobe, Japan: Publ by author. 82 p.

- 1981. Matsushima mycological memoirs No. 2. Kobe, Japan: Publ by author. 68 p.

- 1983. Matsushima mycological memoirs No. 3. Kobe, Japan: Publ by author. 89 p.

- 1987. Matsushima mycological memoirs No. 5. Kobe, Japan: Publ by author. 100 p.

- 1993. Matsushima mycological memoirs No. 7. Kobe, Japan: Publ by author. 75 p.

Mena-Portales J, Mercado-Sierra A. 1987. Piricaudiopsis (Hyphomycetes, Deuteromycotina), nuevo genero enteroblastico de Cuba. Acta Bot Cubana 51:1-5.

Nawawi A, Kuthubutheen AJ. 1989. Canalisporium, a new genus of lignicolous hyphomycetes from Malaysia. Mycotaxon 34:475-487.

$\longrightarrow$ - 1990. Nigulispora gen. nov., a hyphomycete genus with crateriform conidia. Mycotaxon 36:329336.

Peek CA, Solheim WG. 1958. The hyphomycetous genera of H. W. Harkness and the ascomycetous genus Cleistosoma Harkn. Mycol 50:844-861.

Penzig O. 1897. Amallospora, nuovo genere di Tuberculariea. Malpighia 11:461-464.

-, Rao VG, De Hoog GS. 1986. New or critical hyphomycetes from India. Stud Mycol 28:1-84.

- Manoharachary C. 1989. Goosiomyces, a new genus of dematiaceous hyphomycetes from Andhra Pradesh, India. Mycol Res 92:249-251.

Rifai MA, Zainuddin H, Cholil A. 1988. The Javanese species of Tetraploa. Reinwardtia 10:419-424.

Schoknecht JD, Crane JL. 1977. Revision of Torula and Hormiscium species. Torula occulta, T. diversa, T. elasticae, 
T. bigemina and Hormiscium condensatum reexamined. Mycologia 69:533-546.

Subramanian CV, Reddy KRC. 1968. Petrakiopsis elegans, a new Hyphomycete. Sydowia 20:339-341.

Sutton BC. 1980a. Cryptocoryneopsis umbraculiformis gen. et sp. nov. from Australia. Trans Br Mycol Soc 74:393-398.

1980b. The Coelomycetes. Kew, UK: Commonwealth Mycological Institute. $696 \mathrm{p}$.

- 1985. Notes on some deuteromycete genera with cheiroid or digitate brown conidia. Proc Indian Acad Sci (Pl Sci) 94:229-244.
Carmarán CC, Romero AI. 1996. Ramoconidiifera, a new genus of hyphomycetes with cheiroid conidia from Argentina. Mycol Res 100:1337-1340.

- Muhr LE. 1986. Cheiromycina flabelliformis gen. et sp. nov. on Picea from Sweden. Nord J Bot 6:831-836.

Tzean SS, Chen JL. 1989. Two new species of Dictyosporium from Taiwan. Mycol Res 92:497-502.

_ 1990 . Cheiromoniliophora elegans gen. et sp. nov. (Hyphomycetes). Mycol Res 94:424-427.

Van Emden JH. 1975. Three new fungi from Surinam soil. Acta Bot Neerl 24:193-197. 